\title{
El concepto de territorio para la gestión institucional del patrimonio fotográfico sobre derechos humanos: el caso del Archivo Nacional de la Memoria (Argentina)'
}

The concept of territory for institutional management of photographic heritage on human rights: the case of the National Archive of Memory (Argentina)

https://doi.org/10.1590/1982-02672020v28e18

\author{
ANDRÉ PORTO ANCONA LOPEZ² \\ https:/ / orcid.org/0000-0002-2823-1914 \\ Universidade de Brasília / Brasília, DF, Brasil
}

RESUMEM: El ensayo busca discutir el concepto de territorio como base estructurante de las líneas de acervo de instituciones dedicadas a la gestión de documentos fotográficos. La citada definición es fundamental para que tales instituciones puedan cumplir con calidad, su papel en la consolidación y preservación de un patrimonio fotográfico específico de un dicho territorio. Es importante señalar que tal concepción no implica necesariamente el establecimiento de fronteras geográficas, más bien, éstas dependen de la conformación simbólica - y, por supuesto, política - de un conjunto documental y de sus relaciones con la sociedad. En términos concretos se abordará la conformación institucional del Archivo Nacional de la Memoria, en Argentina, y sus conjuntos documentales fotográficos, analizados desde el punto de vista de sus características contextuales y de su relación con el territorio de los derechos humanos.

PALABRAS-CLAVE: Argentina. Archivo Nacional de la Memoria. Derechos humanos. Documentos fotográficos. Territorio archivístico.

ABSTRACT: The essay seeks to discuss the concept of territory as the structuring base of the holdings lines of institutions dedicated to the management of photographic documents. Such definition is fundamental for those institutions accomplish, with quality, their role in the consolidation and

\begin{abstract}
1. Profundización de las reflexiones iniciales presentadas en el XI Seminario Internacional Politicas de la Memoria: Memorias subalternas, memorias rebeldes, organizado por el Centro Cultural de la Memoria Haroldo Conti (Buenos Aires, oct. 2018). Material inédito. Se agradece a Mariana Avramo por la revisión técnica archivística y a Marisa Montrucchio por la revisión gramatical; ambas están exentas de cualquier responsabilidad por eventuales fallos que se puedan encontrar.

2. Doctor en Historia Social y especialista en organización de archivos por la Universidad de São Paulo (Brasil). Docente de la Universidad de Brasilia (Brasil), Facultad de Ciencias de la Información. Coordinador del Grupo de Investigación en Acervos Fotográficos (GPAF-CNPq,) e integrante del Grupo de Trabajo sobre Archivos Fotográficos y Audiovisuales, del Consejo Internacional de Archivos (PAAG-ICA). E-mail: <apalopez@gmail.com>.
\end{abstract}


preservation on a specific photographic heritage territory. It is important to point out that such a conception does not necessarily imply the establishment of geographical borders, rather, they depend on the symbolic - and, of course, political - conformation of a documentary set and its relations with society. In concrete terms, the essay discusses the institutional conformation of the National Archive of Memory, in Argentina, and its photographic documentary holdings, analyzed from the point of view of their contextual characteristics and their relationship with the territory of human rights.

KEYWORDS: Argentina. National Archive of Memory. Human rights. Photographic documents. Archival territory.

RESUMO: O ensaio procura discutir o conceito de território como base estruturante das linhas de acervo de instituições dedicadas à gestão de documentos fotográficos. Tal definição é fundamental para que essas instituições possam cumprir, com qualidade, seu papel na consolidação e preservação de um patrimônio fotográfico específico. É importante destacar que tal concepção não implica, necessariamente, o estabelecimento de limites geográficos, porém depende da conformação simbólica - e, obviamente, política - de um conjunto documental e de suas relações com a sociedade. Em termos mais específicos, o ensaio aborda a conformação do Arquivo Nacional da Memória, na Argentina, e seus conjuntos documentais fotográficos, analisados desde o ponto de vista de suas características contextuais e de suas relações com o território dos direitos humanos.

PALAVRAS-CHAVE: Argentina. Arquivo Nacional da Memória. Direitos humanos. Documentos fotográficos. Território arquivístico. 
UN EJEMPLO INICIAL

Al apreciar a simple vista la figura 1, puede imaginarse que lo que se observa es un registro familiar de una tarde linda, en la cual los chicos salen a jugar en el parque con sus mascotas. Otras conjeturas podrán hacerse cuando nos enteramos de que dicha figura es un recorte de una escena más grande (figura 2):

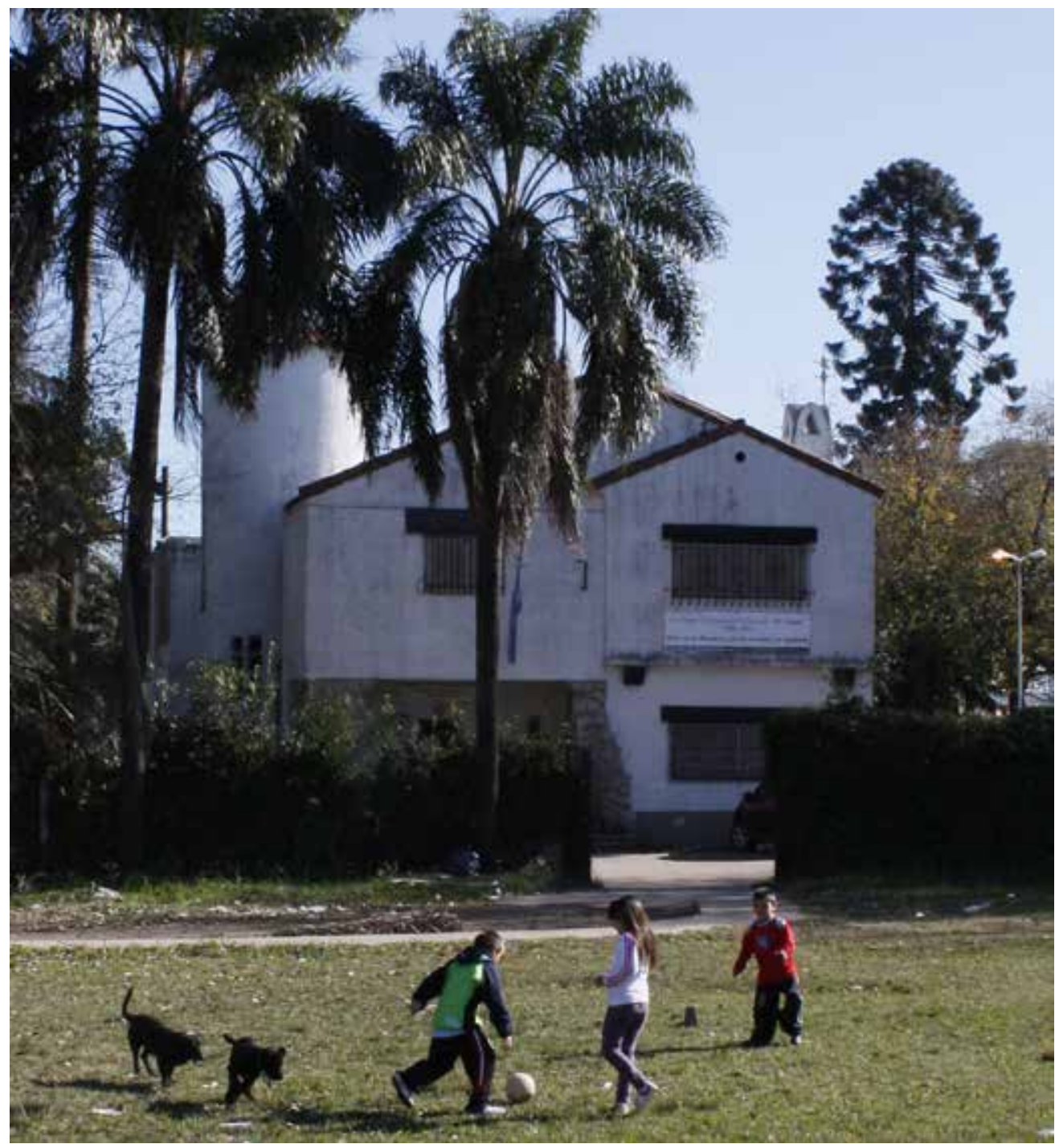

Figura 1 - recorte de la figura 2. Fuente: ANM; recorte hecho por el autor. 
Figura 2 - registro fotográfico del dossier "El Chalet". Fuente: ANM. <El Chalet_Hospital Posadas_006.JPG>.

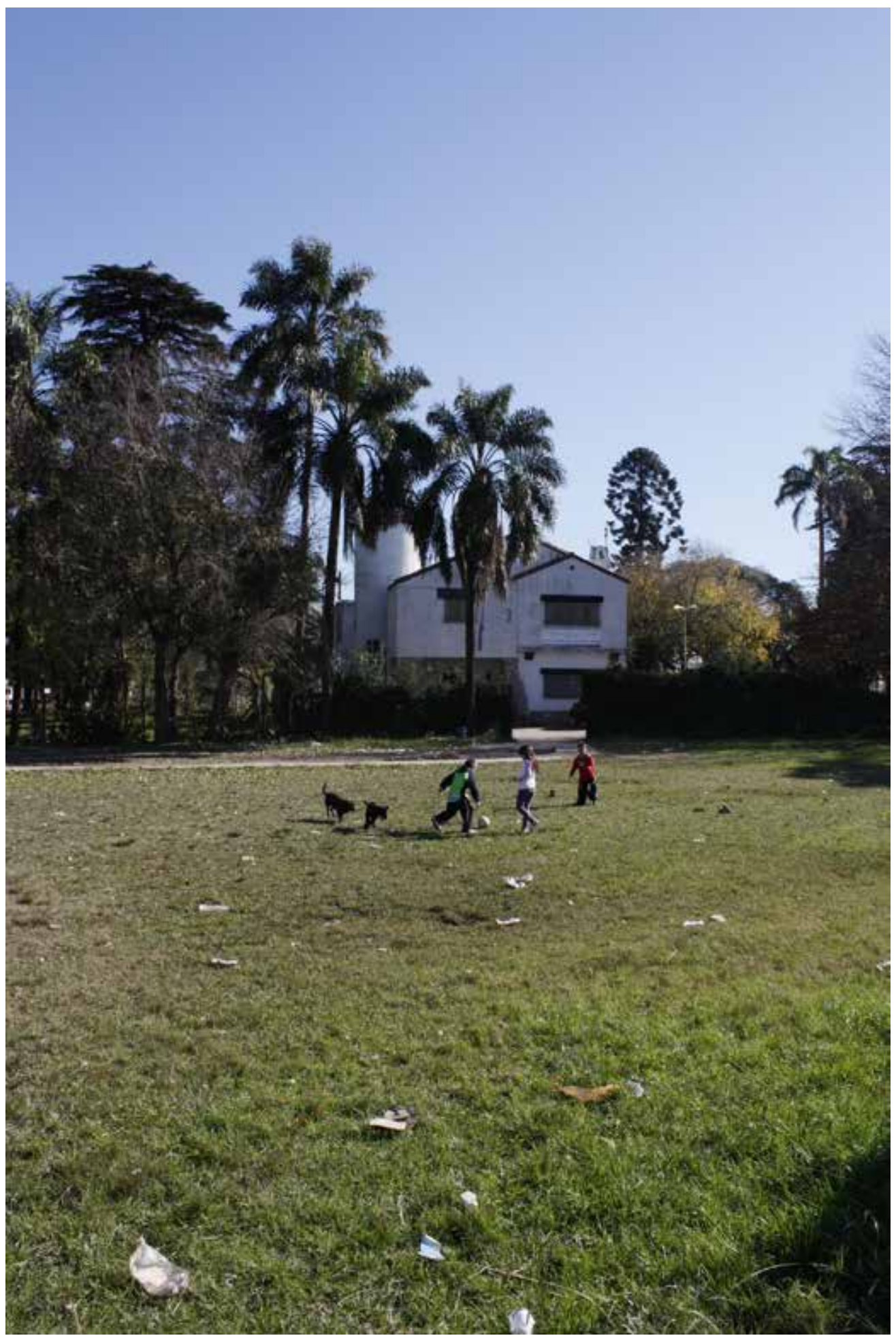




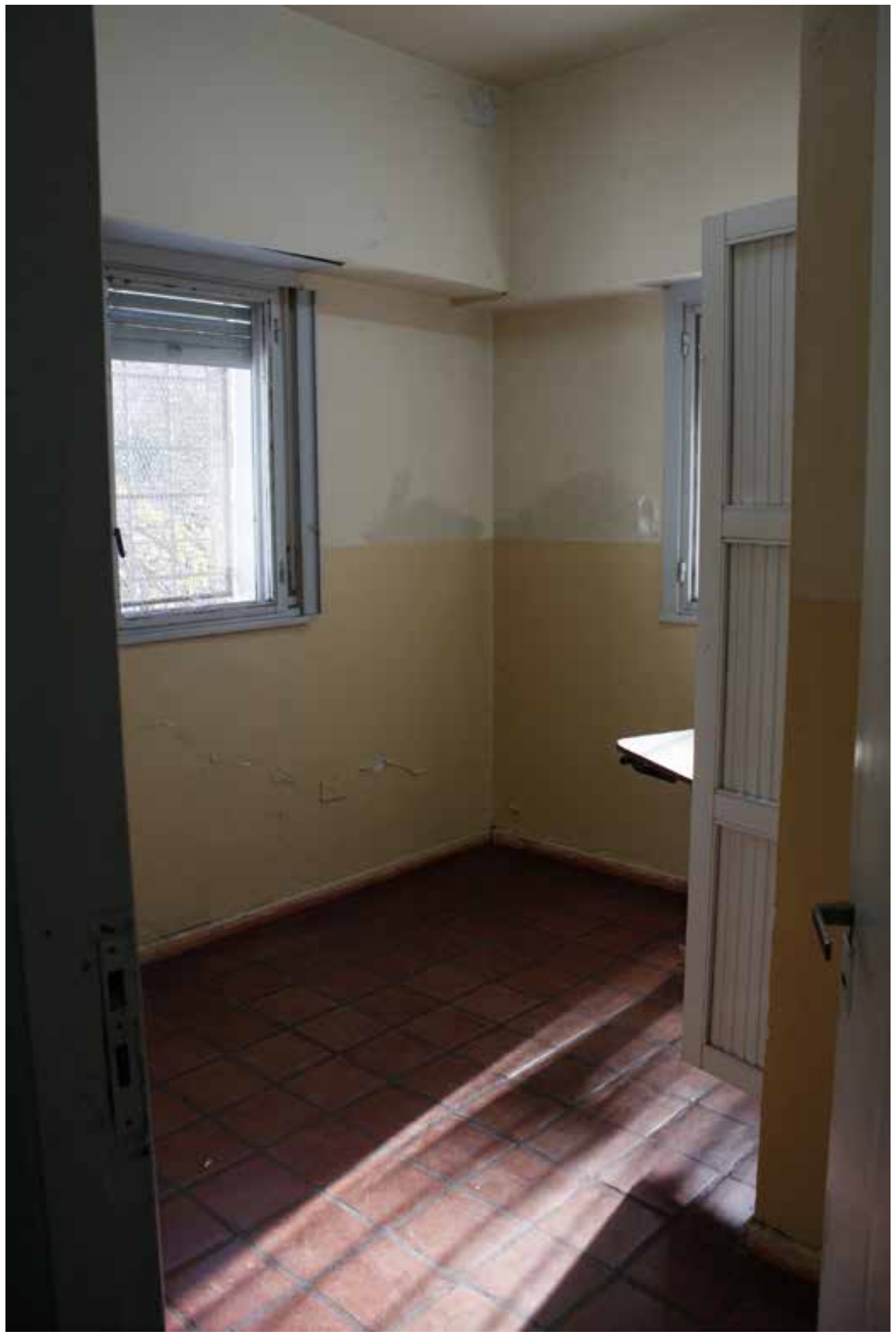

Figura 3 - registro fotográfico del dossier "El Chalet". Fuente: ANM. $<$ El Chalet_Hospital Posadas_002.JPG>. 


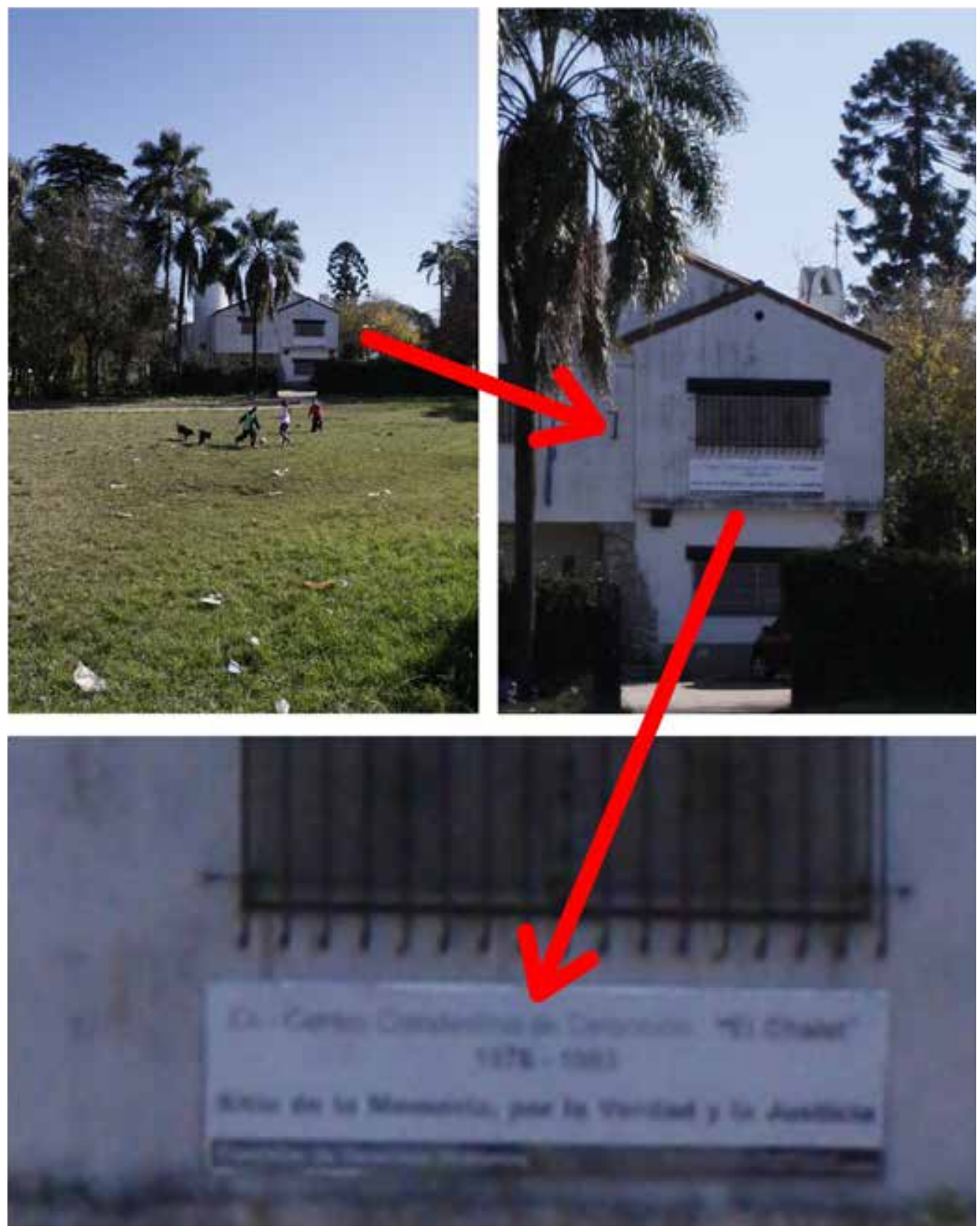

Figura 4 - detalles de la figura 2. Fuente: ANM, con recortes hechos por el autor.

Transcripción: Ex Centro Clandestino de Detención, "El Chalet" / (1976-1983) / Sitio de la Memoria, por la Verdad y la Justicia. 
De ahí se puede imaginar que, quizás, podría tratarse de un registro hecho por la vecindad para, por ejemplo, realizar un reclamo a las autoridades responsables por la limpieza de los parques, por cuenta de la basura que está sobre el césped. Y también se podría plantear otra hipótesis, si nos enteramos de que esa foto viene acompañada de otras más (figuras 3 y 11 y otras no reproducidas acá), permitiéndonos pensar que, quizás, sea una publicidad de una inmobiliaria, que quiere valorizar el barrio como tranquilo, a tal punto de permitirle a los niños que jueguen afuera, mostrando, además, detalles del espacio interno de los departamentos.

Al conocerse mejor el contexto de producción de las fotografías, nos enteramos de una realidad totalmente distinta. Se trata de un dosier fotográfico realizado en el trascurso de las actividades institucionales del Archivo Nacional de la Memoria (ANM) de Argentina. Dentro de esas actividades institucionales, se encuentra la de registrar fotográficamente a los edificios de los ex centros clandestinos de detención (CCD) y de las actividades llevadas adelante por la Red Federal de Sitios de Memoria en todo el país (Refesim). Si nos acercáramos con zoom a la foto inicial podremos notar que se refiere al ex CCD "El Chalet".

Este ejemplo inicial nos indica algunas características fundamentales de los materiales fotográficos de archivo relacionados a los derechos humanos. El primer punto se refiere a la necesidad del contexto para poder comprender el significado iconográfico (o mensaje) de la imagen. ${ }^{3}$ Una identificación pre-iconográfica solamente nos indicaría, para la figura 2, los elementos que permitieron construir las hipótesis iniciales (los chicos, la basura, el inmueble, el barrio). Aunque se pudiera leer la placa del ex CCD sin zoom, igualmente no sería posible vincular las fotografías a la actividad regular y sistemática del ANM. Solamente el contexto nos permite vincular la figura 2 a las demás que integran un dosier y solamente él es capaz de situar su producción en las actividades administrativas, regulares, de un productor archivístico. En ese caso, el dosier gana relieve no solo por retratar el ex CCD, sino porque inserta las fotografías como resultados de actividades de pruebas legales de los ex CCDs como aparatos de violación de los derechos humanos por parte del Estado Argentino. La capacidad de probar legalmente apenas es posible debido al estatuto archivístico de esos documentos, que forman parte del conjunto de documentos producidos por la misma institución (el ANM), en el trascurso de sus actividades regulares, y preservados inviolablemente, como pruebas de tales acciones (de comprobar la existencia de los ex CCD). ${ }^{4}$ El corolario de estas características impone que el ANM esté constituido como un archivo, para que pueda seguir cumpliendo con sus funciones probatorias. Un centro de documentación, a su vez, estaría compuesto por documentos sin la capacidad de prueba jurídica, a pesar de que puedan seguir teniendo un relevante impacto social e histórico.
3. Cf. Panofsky (1991, p. 47-87); para un abordaje del método iconológico de Panofsky, pensado con relación a los documentos fotográficos de archivo, cf. Lopez (1999).

4. Sobre la conceptuación de archivos y sus implicaciones en cuanto a los documentos fotográficos, cf. por ejemplo, Lopez (2009). 
5. La idea de territorio archivístico fue inspirada en las pautas para gestión de documentos fotográficos planteadas por Joan Boadas (2014).

6. Con el fin del régimen militar, el órgano es fusionado con la cartera de la educación (Ministerio de Educación y Justicia: 19831989); luego se convierte en Ministerio de Justicia y Derechos Humanos, agregando y eliminando el tema de la seguridad según los gobiernos, pero sin perder la nomenclatura de derechos humanos (Ministerio de Justicia, Seguridad y Derechos Humanos, 1989-1999; Ministerio de Justicia y Derechos Humanos, 1999-2001; Ministerio de Justicia, Seguridad y Derechos Humanos, 2002-2010; Ministerio de Justicia, y Derechos Humanos, 2010 hasta la fecha).

7. En 2002 la SSDH sube de rango jerárquico tornándose Secretaría de Derechos Humano (SDH). Desde el 2015 el órgano se denomina Secretaría de Derechos Humanos y Pluralismo Cultural (SDHPC).

8. El clásico texto de Michel Duchein (1983) indica que en casos así, de cambios de estructuras, con mantenimiento y/o ampliación de competencias no se debe considerar como modificación del fondo archivístico; tales cambios son apuntados, pero los documentos deben seguir siendo considerados del mismo archivo.

\section{EL TERRITORIO ARCHIVÍSTICO 5 DE LOS DERECHOS HUMANOS Y EL ANM}

En la Argentina, con la vuelta de la democracia en diciembre de 1983, los derechos humanos pasaron a ser un tema de Estado, con una secretaría específica, en un ministerio también conectado al tema. Tras una larga historia de disolución, incorporación y ajustes, en 1989 los derechos humanos pasan a estar permanentemente vinculados a la denominación del Ministerio de Justicia. ${ }^{6}$ Ya el 20 de septiembre de 1984 se crea, por el decreto 3090/1984 (Argentina, 1984), en el ámbito del Ministerio del Interior, la Subsecretaría de Derechos Humanos (SSDH), ${ }^{7}$ con competencias muy explícitas: las de seguir custodiando los documentos que puedan constituir pruebas de las violaciones de los derechos humanos, creados, inicialmente, por la Comisión Nacional sobre la Desaparición de Personas (Conadep), la cual funcionó desde el 15 de diciembre de 1983 hasta el 20 de septiembre de 1984. Ante la preocupación del Estado argentino en lo referido al tema de los derechos humanos y la custodia de sus documentos, casi veinte años después, es creado el ANM, por el decreto 1259/2003, para "obtener, analizar y preservar informaciones, testimonios y documentos sobre el quebrantamiento de los derechos humanos y las libertades fundamentales en que esté comprometida la responsabilidad del Estado argentino y sobre la respuesta social e institucional ante esas violaciones" (Argentina, 2003). La creación del ente solamente formalizó la necesidad institucional de la SSDH de conformar un archivo que pudiera ampliar su actuación en favor de los derechos humanos, más allá de la documentación institucional propia. El ente ANM es creado como un archivo y sigue teniendo prácticas institucionales representativas de ese tipo de institución. Alberga los documentos institucionales de la SSDH y el decreto 1259/2003 enmarca formalmente su territorio archivístico en el tema de los derechos humanos en la Argentina. Al analizar el historial de la institución se puede percibir que el ANM, desde su creación refleja la continuidad de los trabajos, atribuciones y, por lo tanto, de los documentos producidos y generados por el órgano. ${ }^{8}$ Su origen se remonta a la gestión de los documentos de la Conadep y el ingreso sistemático de información sobre violaciones de los derechos humanos sigue, hasta la fecha, dándole continuidad a las actividades de dicha comisión, bajo otra conformación formal; o sea, el ANM le da secuencia al trabajo archivístico con los documentos que son generados constantemente.

En este caso, el término archivo abarca no solo a los documentos archivísticos de los órganos gubernamentales allí recogidos y/o custodiados relacionados al territorio de los derechos humanos, según la competencia dada al ANM - sino también al propio archivo administrativo de la institución. Hay 
que señalar que el concepto de archivo, además de los documentos, también se refiere a la propia institución. Para el cumplimiento de las funciones fundantes de la institución - desde sus orígenes como Conadep - la búsqueda y el acopio, como así también la incorporación de copias de documentos de los más diversos orígenes (personales, de otros entes del Estado, de prensa, etc.) siempre estuvo presente como una actividad institucional. Por lo tanto, tales registros - creados en el seno de la SSDH, SDH, ANM, SDHPC o recogidos en otros lugares deben ser considerados como documentos archivísticos, para que puedan seguir constituyendo pruebas a favor de la defensa de los derechos humanos.

En términos de territorio archivístico se puede considerar que, para el cumplimento de sus funciones, y dentro de su territorio, el ANM incorporó colecciones de carácter privado. El territorio define el espectro de actuación de la institución, en conformidad con su designación formal (en el caso de ente público). Tal designación, muchas veces, puede (y debe ser extensa) para el mejor cumplimiento de la función del ente. También es importante evitar las superposiciones de territorios entre órganos que estén en el mismo ámbito de la administración. Lo cual significa que, si la atribución formal del ANM es ocuparse, a nivel del Estado, de los documentos relacionados a los derechos humanos, otros organismos del Poder Ejecutivo de Argentina deben evitar sobreponerse al ANM en la gestión de los documentos de derechos humanos. La definición del territorio debe tener en consideración la capacidad operativa de la organización, así como su experticia organizacional. El espectro del territorio suele considerar documentos, acervos e informaciones de otros órganos, entes (públicos y privados), además de materiales personales. La profundización en el territorio implica conocer con profundidad el tema a nivel mundial en términos prácticos y académicos. ${ }^{9}$

Al territorio archivístico del ANM vinculado a los derechos humanos se le asignan los objetivos de relevar archivos y documentación relacionada con el terrorismo de Estado en la Argentina, además de articular los objetivos de Memoria, Verdad y Justicia mediante la generación de acciones conjuntas entre las diferentes jurisdicciones a nivel nacional, entre los países del Mercosur y en el plano internacional. Según la guía en línea del Instituto de Políticas Públicas de Derechos Humanos Mercosur (IPPDH) cabe al ANM aún clasificar y preservar la documentación que se le ingresa institucionalmente (IPPDH. s/f). El mismo IPPDH indica que el ámbito de actuación de la entidad incluye distintas actividades relacionadas a los derechos humanos, afirmando su experticia en el tema, o sea, su territorio archivístico:
9. Un ejemplo interesante, muy ilustrativo, es el Archivo Municipal de Girona (AMG), cuyo territorio archivístico transcendió los límites de la gestión de los documentos de la municipalidad gerundense para convertirse en el propio municipio y su comunidad, a lo largo del tiempo, inclusive. De ahí resultó que el AMG, entre otras cosas, pasó a dedicarse a la busca, acopio y copia de fotografías de la ciudad, desarrollando una experticia en la gestión de documentos fotográficos que lo puso cono uno de los principales centros de referencia del mundo en tratamiento fotográfico. 
10. La información utilizada por el IPPDH se basaba en la antigua página del ANM, vigente en 2017, que pasó por una revisión tras la implantación del portal Argentina.gob.ar. La información actual disponible en la página del ANM es más resumida (<https:// bit.ly/2Zc5IVZ $>$ ), pero tales ámbitos de actuación siguen válidos y están distribuidos en diferentes partes del sitio web.

11. Se trata de la versión del informe final, difundida como libro, que influenció directamente a un trabajo similar en otros países del continente, como, por ejemplo, en Brasil, Arquidiocese de São Paulo (1986).

12. Esa acepción de guarda de documentos con fines de prueba para remontar a las propias actividades administrativas de una institución, persona u órgano representa la definición más clásica de lo que es un archivo, cf. Jenkinson (1966 [1922], p. 4).

13. Conadep (1985, p. 13).

14. A diferencia de la Conadep, el proyecto Brasil: Nunca Mais no fue conformado por el Estado, sino por la sociedad civil, con la participación de abogados que pudieron acceder a los expedientes del Supremo Tribunal Militar, en plena dictadura y hacer la recopilación documental de manera despistada, hasta la conclusión del proyecto, cf. Camargo (2002). Ambos proyectos, igualmente, trataron de conformar pruebas de la actuación indebida del Estado a través de sus propios documentos. La diferencia es que la Conadep, al ser un ente estatal, transforma en documento de archivo todo el material que recoge o recibe.
- Difusión y promoción de las actividades de todas las áreas que integran el ANM.

- Coordinación de la Refesim, para articular las políiticas nacionales, provinciales y municipales de memoria e investigación que se llevan adelante en los ex CCDs y otros espacios vinculados con el terrorismo de Estado en todo el país.

- Gestión de los fondos y documentos transferidos y/o custodiados en el ámbito del territorio, entre ellos: los documentos de la Conadep, los archivos de la SDH, el Archivo de Prensa de la Presidencia de la Nación, obrante en el ANM; los alcanzados por las Leyes Reparatorias, también custodiados en la $\mathrm{SDH}$, y los demás existentes en el ámbito nacional.

- Colaboración con la experticia en derechos humanos, a los estados provinciales, municipales y a la Ciudad Autónoma de Buenos Aires, ofreciéndoles la coordinación de sus archivos locales en la temática.

- Gestión de documentos fotográficos y audiovisuales relacionados con el quebrantamiento de los derechos humanos en el Estado argentino y con hechos históricos relevantes vinculados a la materia de su competencia, posibilitando la formación de un patrimonio propio del ANM.

- Dirección ejecutiva de la Unidad Especial de Investigación de la desaparición de niños como consecuencia del accionar del terrorismo de Estado.

- Publicación de distintos materiales con el fin de contribuir a la defensa de los derechos humanos y de las libertades fundamentales por medio de la circulación de la información y el conocimiento. ${ }^{10}$

El ANM, desde su creación - que se remonta a las actividades de la Conadep y al informe Nunca Más (CONADEP, 1985)"11 - y debido a su actuación destacada en el territorio de los derechos humanos, indican claramente el marco archivístico de la constitución de pruebas por el Estado - ya que la Conadep fue constituida como un ente estatal - para remontarse a sus propias actividades. ${ }^{12} \mathrm{El}$ trabajo de la Conadep tuvo la capacidad de constituir pruebas dentro del Estado en contra de la actuación anterior del mismo a través "[...] del aporte testimonial y documental recibido $[\ldots]^{13}$, inaugurando una metodología inédita para América Latina. ${ }^{14}$ La necesidad de recopilación y/o aporte documental para la constitución de pruebas contra el terrorismo de Estado es una de las características de los archivos de derechos humanos. Archivísticamente hablando, se trata de reconstituir la verdad de los hechos de manera legalmente sostenible, con capacidad, si fuera el caso, de amparar juicios y demás acciones jurídicas. 
El termino memoria, aunque para algunos pueda ser incómodo, se justifica porque se trata de una reconstrucción (total o parcial, según el caso) para el establecimiento (o nueva creación) del archivo que fue intencionalmente oculto lo destruido). ${ }^{15}$ De esta manera, no correspondería comprender la creación del ANM en el seno de una política estatal de la memoria ${ }^{16}$ (a pesar del término), sino de una política muy claramente direccionada a la constitución de pruebas archivísticas. La práctica respeta los conceptos archivísticos de integridad, orden original y procedencia, una vez que los documentos, al ser recogidos (o recopilados) se convierten en nuevos documentos de archivo, producidos por dicho ente estatal, designado para las tareas de investigación de las violaciones de los derechos humanos por parte del Estado. La memoria, en esos casos, también representa una herramienta capaz de permitirle al ciudadano actuar afirmativamente con los documentos probatorios en el sentido de marcar su oposición a las violaciones de los derechos humanos: "Más allá de la función probatoria documental del archivo está su condición de fuente de [...] acciones performativas y políticas [...]". ${ }^{17}$

La recopilación y acopio de materiales que puedan conformar el archivo (en el sentido archivístico pleno) suele contar con documentos fotográficos, sea por sus características de insumos para la memoria - herramienta fundamental en esos casos - , sea por su fuerza elocutoria, cuando archivísticamente contextualizados. ${ }^{18}$ En ese sentido, los documentos fotográficos pueden ser considerados como elementos fundamentales en los archivos de derechos humanos, en función de su capacidad probatoria - cuando se encuentran archivísticamente conformados. Laila Di Pietro indica que "la organización archivística puede garantizar al documento fotográfico el poder de prueba y, junto a otros documentos, producidos o acumulados, formar parte de diferentes procesos en el contexto de la lucha en contra de la violación de los derechos humanos" (Di Pietro, 2016; traducción libre)". La acepción archivística del ANM es una condición sine qua non para que su material fotográfico pueda tener la necesaria capacidad de prueba, tan fundamental en la historia reciente de la Argentina para la defensa de los derechos humanos - en contra del terrorismo de Estado - , en una política archivística iniciada con la creación de la Conadep el 15 de diciembre de 1983 y consolidada con la formalización del ANM, el 16 de diciembre de 2003.

\section{MATERIALES FOTOGRÁFICOS DEL ANM}

Según la "Guía de Fondos: documentos fotográficos" del ANM (2018),19 sus materiales fotográficos están divididos en cuatro grandes grupos:
15. Véase como ejemplos de situaciones similares en diferentes países, el estudio profundo de Ludmila Catela y Elizabeth Jelin (2002).

16. Tampoco se podría pensar en la idea de congelamiento de una memoria, ya que la memoria, en este caso, es usada como herramienta, sobre todo testimonial, para la recopilación de informaciones y documentos - Conadep (1985, p. 13) - que tendrán las cualidades archivísticas de pruebas jurídicas.

17. Giraldo Lopera et al. (2015, p. 27). En esa acepción es importante notar que "estar más allá" del archivo no representa su denegación, por lo contrario: reafirma su condición sine qua non de prueba (archivística) para que se pueda actuar políticamente.

18. Sobre la necesidad del contexto archivístico para la correcta comprensión de los significados de las fotografías (en cuanto pruebas) cf. Lopez (2011a.).

19. Esa publicación presenta, de manera somera, la descripción y caracterización de cada subconjunto documental. No coincidimos con la idea de fondo fotográfico en un archivo que agrega documentos de diferentes géneros y soportes, pero no está en los objetivos de ese texto la discusión sobre la política de la institución en cuanto a la organización archivística de los documentos, sino el debate en torno a su carácter de archivo y no de centro de documentación. 
20. En la relación acá expuesta, los términos fueron ajustados para una caracterización más precisa de los conjuntos documentales. El documento original del ANM está disponible en línea (ANM, 2018).
1. Materiales Fotográficos Institucionales ${ }^{20}$ SDH-ANM Ifotografías producidas y conservadas por la Conadep, SSDH, SDH, SDHPC y por el ANM en el desempeño de sus actividades).

2. Colecciones fotográficas de otras instituciones (fotografías de diversas instituciones y organismos que conservan imágenes de interés para el ANM, que fueron relevadas con fines específicos vinculados a la promoción de los derechos humanos).

3. Colecciones de autores (colecciones privadas de fotógrafos y reporteros gráficos, vinculadas a los derechos humanos, que han autorizado la consulta pública).

4. Colecciones particulares (donaciones de material fotográfico recolectado, seleccionado y conservado por particulares, que remiten temáticamente a cuestiones vinculadas a la problemática de los derechos humanos).

Aparte de los 4 grandes grupos que integran el acervo fotográfico del ANM se encuentra también la Fototeca de la Asociación de Reporteros Gráficos de la República Argentina (Argra). En el año 2005 se firmó un convenio entre el Argra y el ANM para albergar su fototeca de aproximadamente 2.000.000 de fotografías.

La publicación no hace referencia a los principios teóricos, pero la división de los conjuntos respeta, claramente, el principio de procedencia; la identificación de cada conjunto y sus respectivos subconjuntos, igualmente, se encuentra en conformidad con los marcos teóricos de los archivos, como puede percibirse en sus caracterizaciones, con fotos ilustrativas para los conjuntos institucionales, cedidas por el ANM en agosto de 2017.

\section{Materiales Fotográficos Institucionales - Conadep:}

Son cerca de 2020 fotos tomadas por Enrique Shore en las inspecciones oculares realizadas por los investigadores y los sobrevivientes a 38 ex CCDs; y 2080 reproducciones más de las fotografías que acompañan los legajos y primeras denuncias realizadas por los familiares de detenidos-desaparecidos. Se trata de documentación institucional, propia de archivos, conservada y tratada como tal. Las fotos de Shore fueron de gran relevancia para reconstruir, identificar y registrar los ex CCDs. 


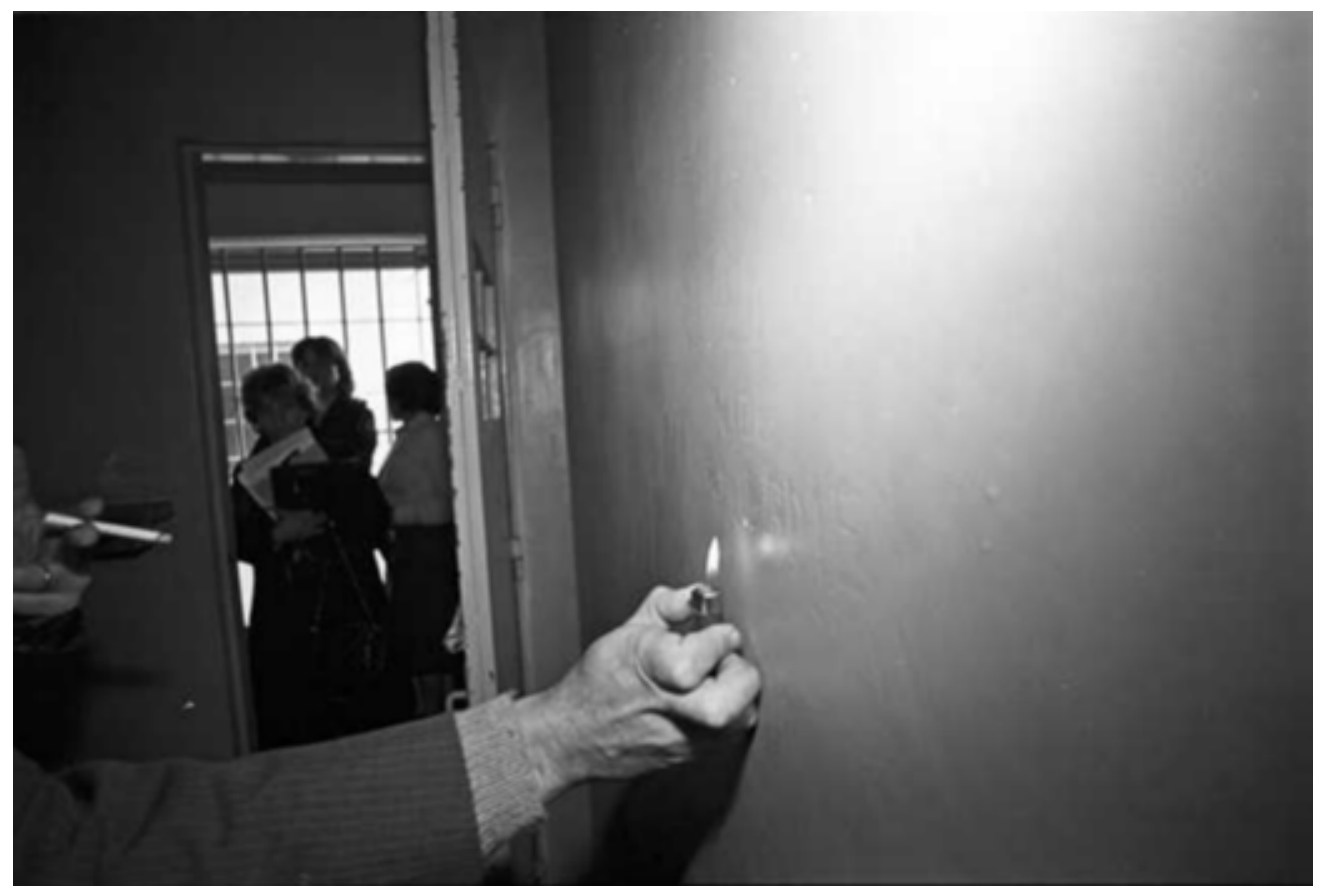

Figura 5 - registro fotográfico de inspección ocular a los ex CCDs. Fuente: ANM; <CO2 239e_01CNDP-08 0897.jpg>.

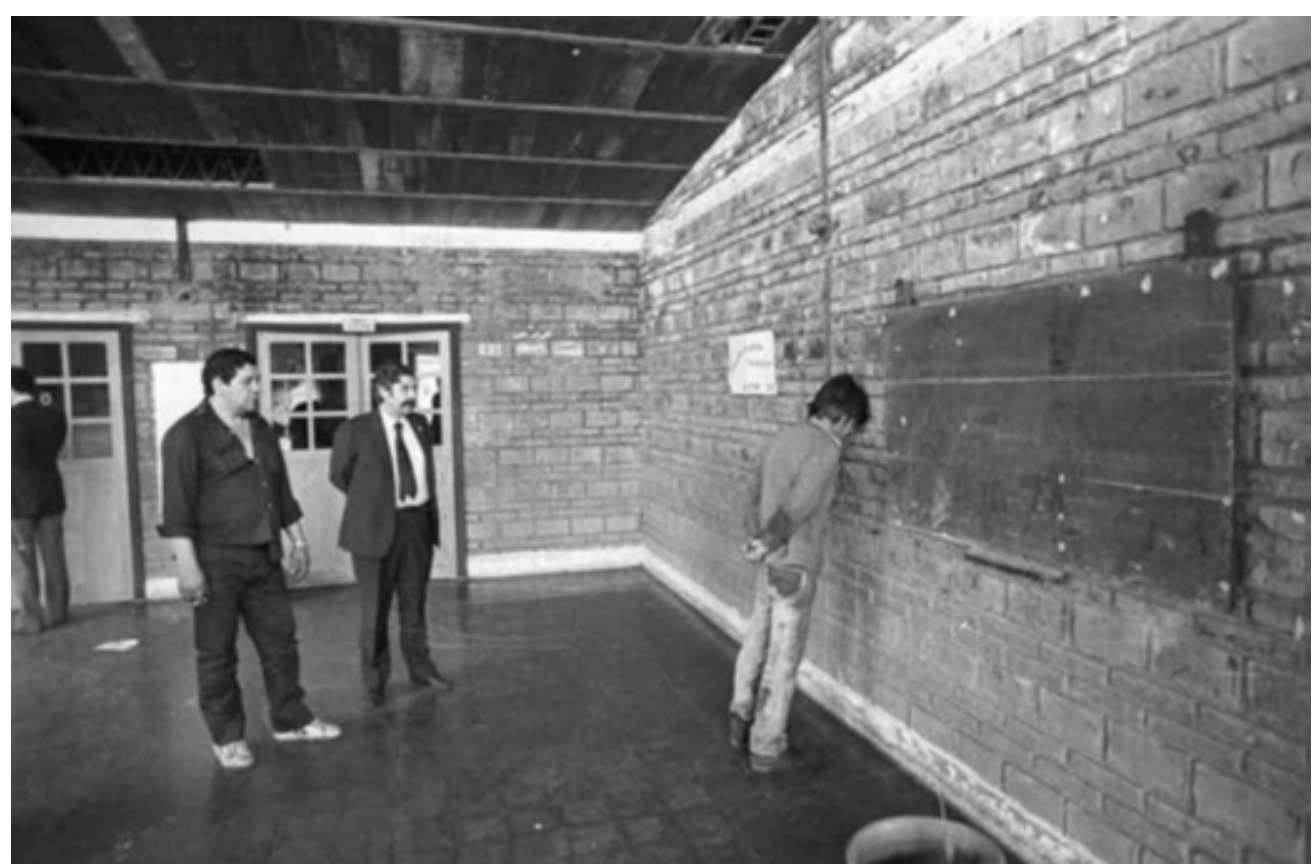

Figura 6 - registro fotográfico de inspección ocular a los ex CCDs. Fuente: ANM; <C04_471a_01CNDP-08 1943.jpg>. 
Materiales Fotográficos Institucionales - Actividades institucionales y de promoción de los derechos humanos:

Son cerca de 3000 fotos producidas por el área audiovisual en sus funciones desde el año 2004, que se centran en tres ejes principales: la recuperación y puesta en valor del Espacio para la Memoria (ex Esma) y en los numerosos actos, actividades y visitas de autoridades políticas y personalidades del movimiento de derechos humanos desarrolladas dentro del predio; las actividades llevadas adelante por la Refesim en diferentes ex CCDs de todo el país; imágenes tomadas durante el desarrollo de los juicios por crímenes de lesa humanidad. Es otro conjunto que también está compuesto por documentación propia de archivo y tratada como tal. Son fotografías producidas por el ente en su rol institucional de lucha contra el terrorismo de Estado, dentro de su territorio archivístico de los derechos humanos.

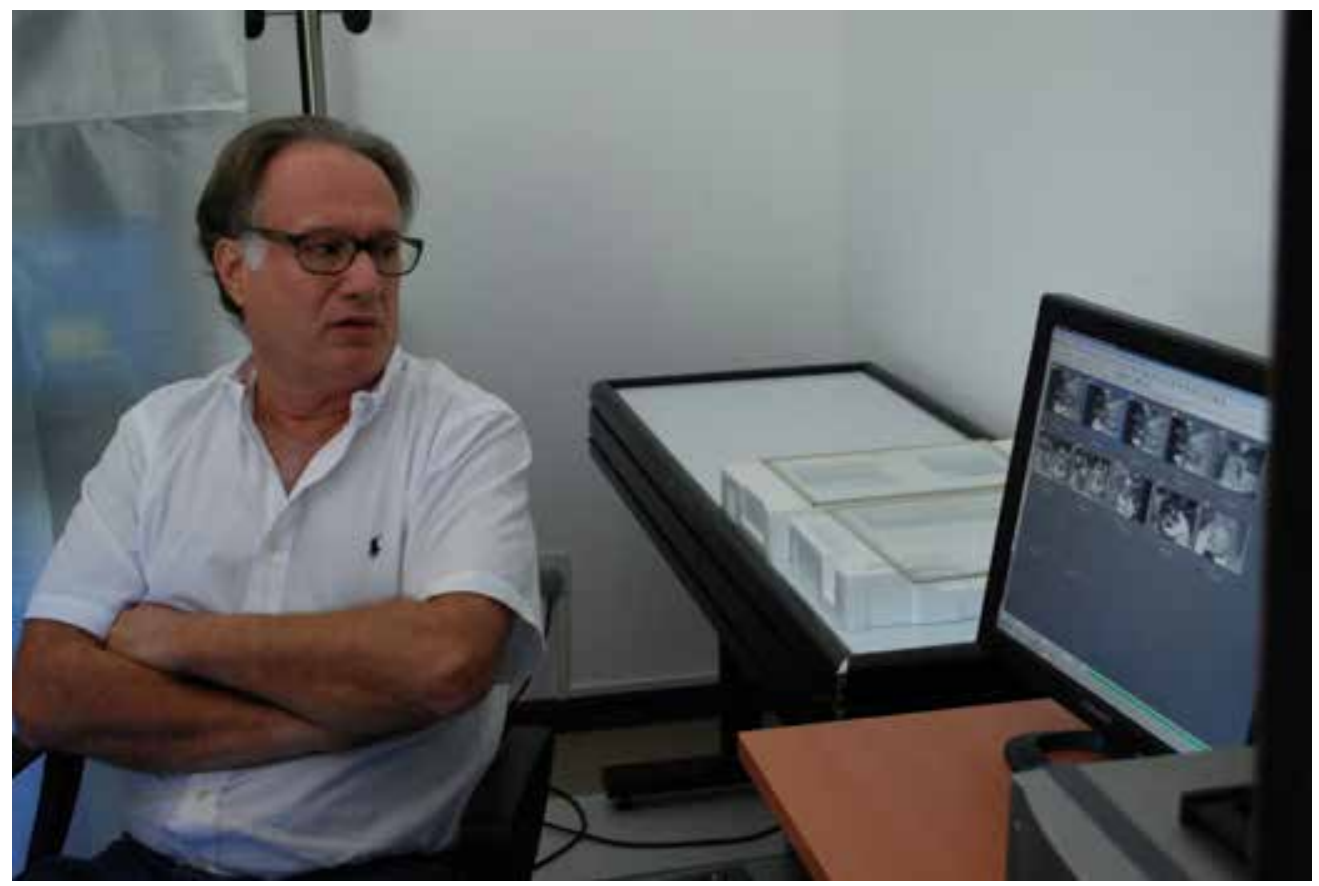

Figura 7 - registro fotográfico de actividad administrativa: visita de Enrique Shore al ANM. Fuente: $A N M$; $<$ DSC_O $112 . J P G>$. 


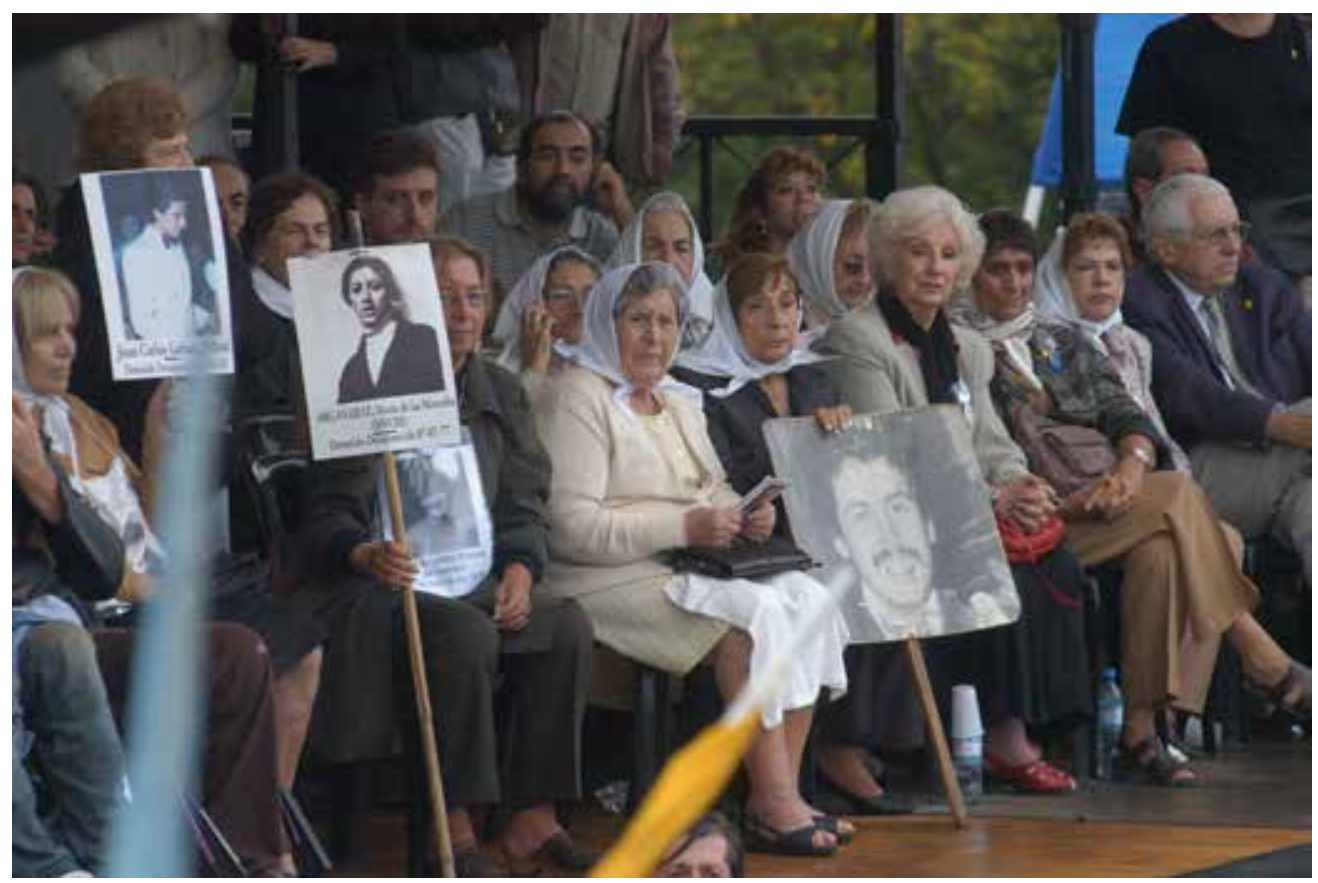

Figura 8 - registro fotográfico de actividad administrativa: acto con familiares de desaparecidos en el ANM. Fuente: ANM. <FF-01-01-0084.JPG>.

\section{Materiales Fotográficos Institucionales - Registro de edificios ex CCDs:}

Son fotografías producidas por: el Espacio Memoria, los equipos de conservación del ANM, la Refesim y por los familiares de detenidos-desaparecidos. Los conceptos de archivo y procedencia siguen intactos, en la medida que el acopio de fotografías de otros orígenes forma parte de las funciones institucionales del ANM y estén directamente vinculadas a su actividad principal como institución, históricamente continuadas. La documentación fotográfica de esos ex CCDs, y de las distintas actividades que allí se desarrollan, inclusive luego de ser identificados, sigue como una actividad institucional de rutina. 
Figura 9 - registro fotográfico del ex CCD Club Atlético, en Buenos Aires. Fuente: ANM. <Atlético_Excavación_005.jpg>.

Figura 10 - registro fotográfico de actividad de inauguración del ex CCD "La Ribera", en Córdoba, como sitio de memoria. Fuente: ANM. <Apertura La Ribera_O0 1.JPG>.
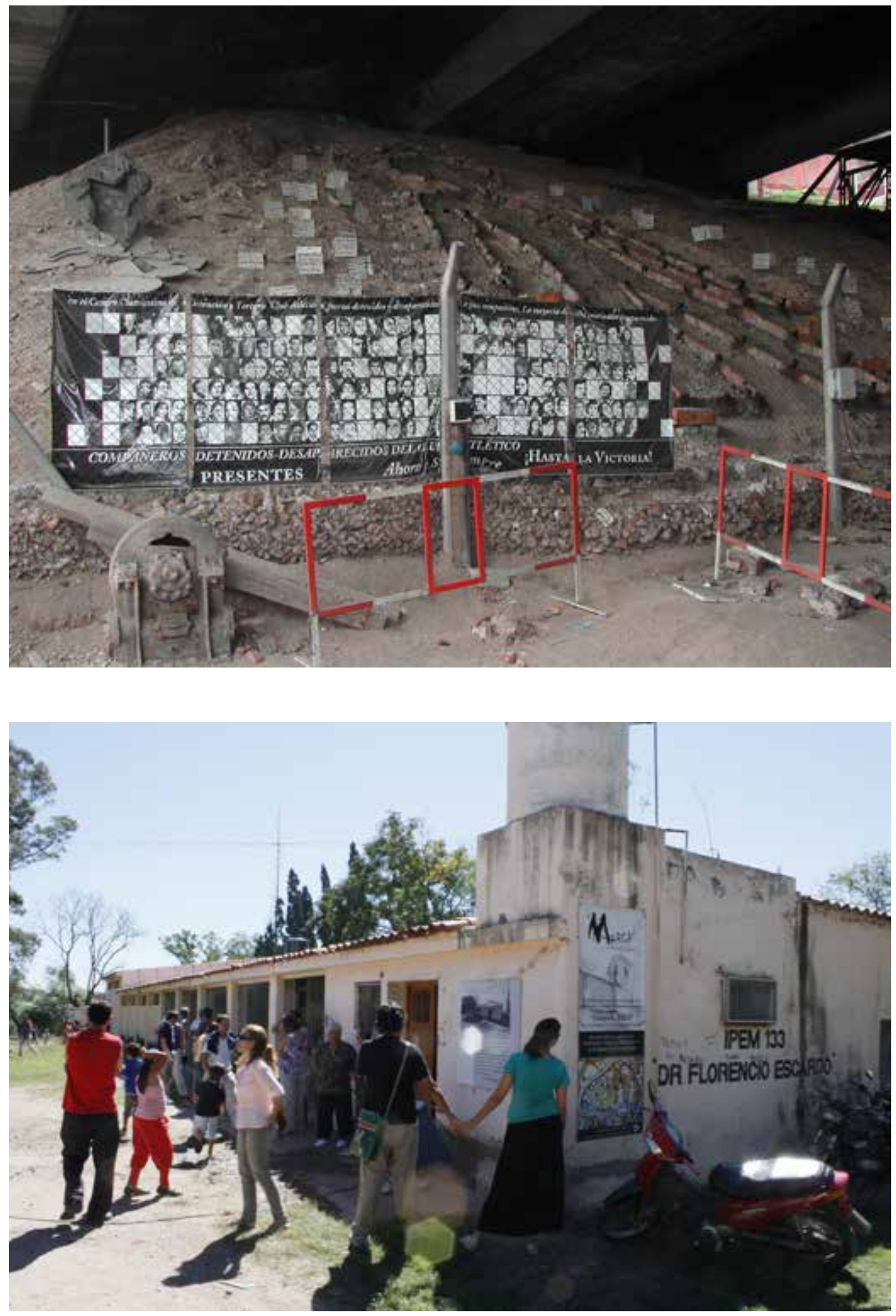


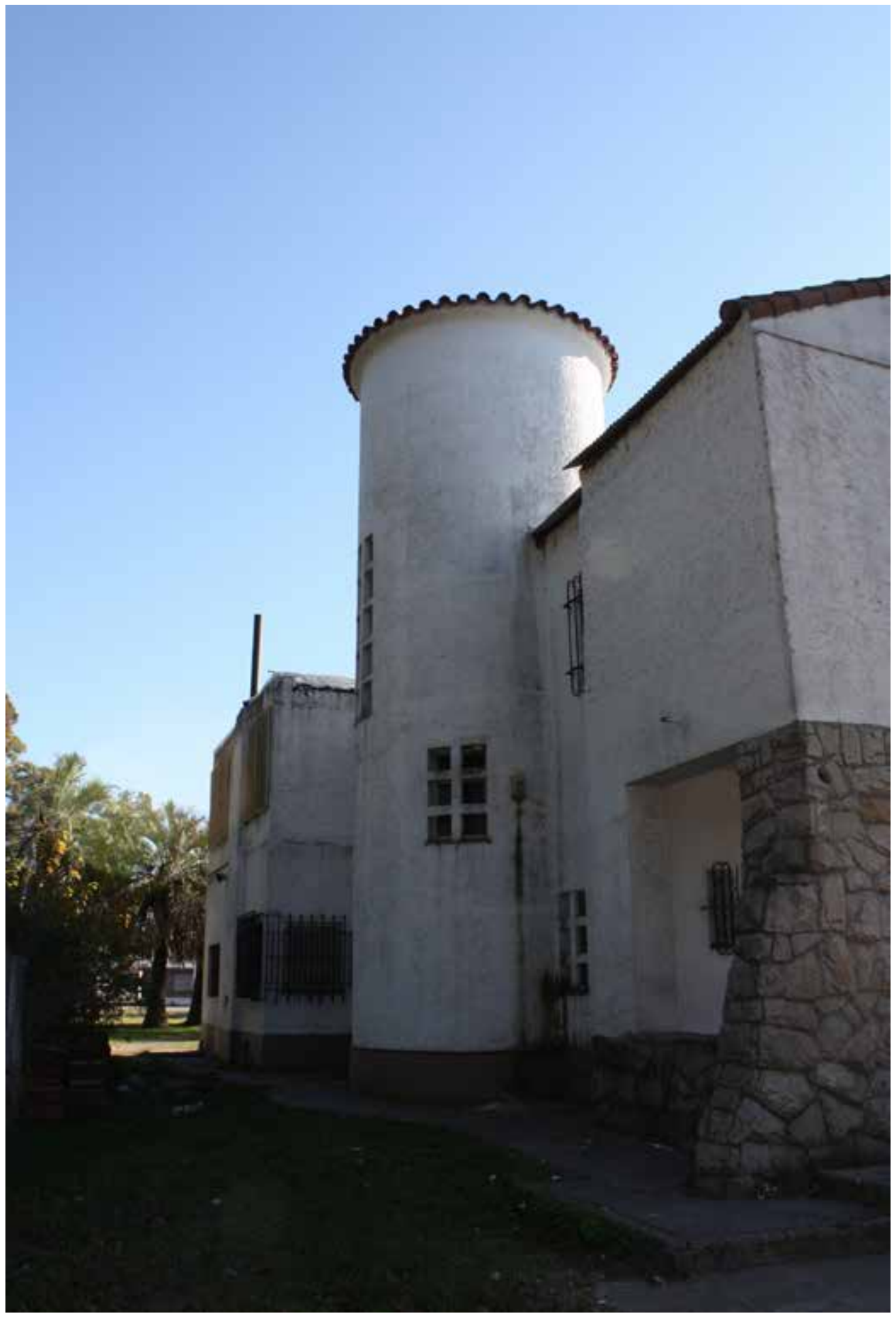

21. Véase, aún en ese texto, las figuras 2 y 3 .

Figura 11 - registro fotográfico del ex CCD "El Chalet", en Buenos Aires $^{21}$. Fuente: ANM. $<$ El Chalet_Hospital Posadas_011.JPG>. 
22. Dichos ítems disponen sobre los objetivos del ANM de la siguiente manera: "a) Contribuir a mantener viva la historia contemporánea de nuestro país y sus lecciones y legados en las generaciones presentes y futuras", "e) Desarrollar los métodos adecuados, incluida la duplicación y digitalización de los archivos y la creación de una base de datos, para analizar, clasificar y archivar informaciones, testimonios y documentos, de manera que puedan ser consultados por los titulares de un interés legítimo, dentro del Estado y la sociedad civil, en un todo conforme a la Constitución, los instrumentos internacionales de derechos humanos y las leyes y reglamentos en vigencia" (Argentina, 2003, art. $3^{\circ}$ ).

\section{Materiales Fotográficos Institucionales - Masacre de Pando:}

El conjunto está constituido por el registro fotográfico tomado, además de un registro audiovisual vinculado, de las actividades de la Comisión Especial de Unasur, conformada con la finalidad de investigar la masacre ocurrida el 11 de septiembre de 2008 en la localidad boliviana de Pando. Dicha comisión fue conformada por miembros de los países de la Unasur y fue presidida por el jurista argentino Rodolfo Mattarollo, experto en derechos humanos, fundador en su exilio durante el régimen militar, de la Comisión Argentina de Derechos Humanos (Cadhu), desempeñándose como jefe de gabinete de la SDH del 2003 al 2005. A pesar de no estar directamente vinculado a las actividades desarrolladas por el ANM, ese conjunto documental se relaciona con la experticia del ente en su territorio archivístico debiendo, por lo tanto, ser considerado como material típico de archivo, fruto de sus actividades, y recibido en el trascurso de su existencia. Tales actividades están manifiestas en diversas partes de su decreto de creación, con especial indicación en el artículo $3^{\circ}$, que señala cuales son los objetivos del ANM: "d) Preservar informaciones, testimonios y documentos necesarios para estudiar el condicionamiento y las consecuencias de la represión ilegal y el terrorismo de Estado en la República Argentina, su coordinación con los países del cono sur y sus demás manifestaciones en el exterior y contribuir a la coordinación regional y subregional de los archivos de derechos humanos" (Argentina, 2003, art. 3", destacamos).

\section{Colecciones fotográficas de otras instituciones:}

Se trata de copias de material fotográfico de otras instituciones, vinculadas a los derechos humanos. Ese conjunto, en términos más estrictos, no debería ser considerado como parte de un archivo. En realidad, no son documentos archivísticos del ANM y, por lo tanto, deben ser tratados como colecciones. Sin embargo, forman parte del archivo-institución ANM, precisamente por vincularse a su experticia y al territorio archivístico de los derechos humanos. El decreto de creación, sobre todo en los ítems " $a$ " y "e" del artículo $3^{\circ}$ señala, de modo muy indicativo, esa atribución. ${ }^{22}$ A la argumentación de que el marco normativo legal fue mal conformado, en términos archivísticos, se contrapone la necesidad de que los archivos tienen que incorporar materiales - debidamente separados y tratados según su procedencia y naturaleza - relacionados a su territorio, para el mejor cumplimiento de sus funciones archivísticas y sociales; es el caso de los archivos del poder público. 
En ese apartado hay copias fotográficas de material relevante para el territorio de los derechos humanos del Archivo General de la Nación (AGN) y del Instituto Nacional de Investigaciones Históricas Eva Perón (Inihep). En este último, se encuentran fotos relacionadas al movimiento femenino, incluyendo material relativo al bombardeo de la Plaza de Mayo, ocurrido en el año 1955. Del Centro de Información Judicial (CIJ), están las fotografías de Martín Kraut en juicios por delitos de lesa humanidad. De la Agencia de Noticias Télam fueran copiadas fotografías vinculadas a la última dictadura cívico-militar y al período de la transición a la democracia. Del Diario Jornada de Chubut existen fotografías vinculadas a acontecimientos políticos y sociales ocurridos en dicha provincia durante las décadas de 1960 y 70, incluyendo los hechos vinculados a la Masacre de Trelew. La copia de fotografías dispersas en otras instituciones representa una garantía de información al ciudadano interesado en los derechos humanos, ya que no siempre tienen información de su existencia o, a veces, no les es permitido el acceso. Esas cinco colecciones de otras instituciones, en el momento de la finalización de este texto, no habían publicado ninguna información sobre sus existencias en los respectivos sitios web. ${ }^{23}$

\section{Colecciones de autores:}

Son once colecciones de autores conformadas por los propios fotógrafos, que pueden variar desde un conjunto grande de fotos de diferentes eventos relacionados a la violación de los derechos humanos, hasta series completas de eventos únicos. Se trata de colecciones vinculadas a los materiales de un archivo, cuya convivencia en el acervo de la institución es completamente natural, mientras que el principio de procedencia sea respetado y que la integridad de la colección esté totalmente garantizada. Según la guía fotográfica del ANM, esas colecciones "[...] incluyen la producción personal de fotógrafos y reporteros gráficos que han autorizado la consulta pública de sus imágenes. Los autores contribuyen con una visión personal de momentos históricos claves de nuestro país, poniendo el acento en los movimientos sociales surgidos durante las últimas décadas, en la represión estatal y en las estrategias que los distintos actores sociales articularon para la obtención y ampliación de derechos". ${ }^{24}$ La existencia aislada de esas colecciones no constituiría elementos suficientes para la caracterización de un archivo. En el caso del ANM, tales materiales se encuentran debidamente organizados con respecto a su naturaleza privada, representando importante aporte para la ampliación de material relevante relacionado al territorio archivístico de la institución. Son colecciones importantes para el tema de los derechos humanos, cuyo ingreso al ANM les permite desarrollar su potencialidad
23. En las páginas mencionadas a continuación no se pudo encontrar ninguna información específica sobre los materiales fotográficos vinculados a los derechos humanos, siendo que en alguna de ellas ni siquiera fue posible encontrar informaciones sobre acceso a materiales fotográfi cos: AGN: <https://bit. ly/360vRZc $>$ y <https://bit. ly/2LrTDUs $>$; Museo Evita: <https://bit.ly/3fVnqTw> y <https://bit.ly/2YZ8zkJ>; Centro de Información Judicial: la búsqueda por Martín Kraut retorna vacía en $<$ https://bit.1y/3dHrPr1>; la Agencia de Noticias Télam suspendió su página web en $<$ http://www.telam.com. ar/> cuando elaboramos la búsqueda en septiembre de 2018, actualmente la página trabaja con un buscador que retorna una cantidad expresiva de imágenes, pero sin ningún tipo de clasificación; el Diario Jornada de Chubut no permite búsqueda anteriores al 2012 en su página en <https://bit.ly/2WtcIf9>.

24. ANM (2018, p. 4). 
en ese campo. En el caso de que no estuvieran allí conservadas, tenderían a ser un material disperso de bajísimo potencial de uso. Parte de la función social de un archivo es amparar a materiales relevantes de su territorio archivístico, en el cual su experticia los hace ser un referente.

2. Colecciones particulares:

Las tres colecciones particulares representan fotografías colectadas o recompiladas por investigadores de temas políticos y/o históricos, pudiendo contemplar copias de copias y materiales mal referenciados. Según el ANM son conformadas "[... ] por donaciones de documentos de diverso tipo tales como fotografías, volantes, afiches, recortes de prensa, etc. que fueron recolectados, seleccionados y conservados por los donantes de acuerdo a sus propios intereses. Estas colecciones particulares constituyen una selección realizada por el ANM de las colecciones originales creadas por estas personas." $25 \bigcirc$ sea: es una elección de la institución, volcada a los intereses de su territorio archivístico, hecha a partir de una elección anterior, realizada por los coleccionistas, cuando ellos conformaron los conjuntos. Esas colecciones tienen bajo valor archivístico y componen el acervo del ANM como un material de apoyo a la investigación. Igualmente, la presencia de las mismas está justificada por la experticia del ente en el territorio archivístico de los derechos humanos.

\section{CONCLUYENDO...}

El concepto de territorio trabajado por el ANM, definido legalmente - y ratificado por acciones prácticas a lo largo de su existencia - ubica a la institución en el tema de los derechos humanos. Su acervo (incluyendo su archivo) está conformado bajo esa acepción, en absoluta adecuación a los marcos teóricos de la Archivología, tanto por su material orgánico e institucional, como por las colecciones recogidas, que son fundamentales para el pleno cumplimento de su función institucional. La existencia de colecciones no compromete el estatuto archivístico de la institución si éstas están debidamente distinguidas. En el caso del ANM eso se verifica en la práctica, a pesar de que su guía fotográfica (ANM, 2018) mezcle los conceptos de fondo y colección. El problema existe, pero se trata de una cuestión de ajuste puntual de la terminología empleada, una vez que existe la separación física e intelectual del material institucional, orgánico, archivístico del material no- 
orgánico (las colecciones). Aparte de la gestión de los documentos, el órgano es nacional e internacionalmente reconocido como un centro de experticia con relación al tratamiento técnico de documentos relacionados al tema de los derechos humanos. Los materiales fotográficos institucionales logran estar debidamente contextualizados, permitiendo que se pueda comprender su organicidad archivística.

Son justamente esos materiales institucionales que representan $-y$, al mismo tiempo, garantizan - el DNA archivístico del ANM, una vez que el archivo, como institución, se caracteriza por la gestión documental del Estado, promoviendo la custodia y el acceso de sus documentos administrativos, con el objetivo de brindar a los ciudadanos informaciones sistemáticas, archivísticamente estructuradas y consistentes, que permitan dar a conocer las acciones efectivamente desempeñadas por los entes públicos (Cf. Lopez, 2011 b). Dicho conjunto corresponde a la base documental de la Conadep y guarda los documentos producidos y acopiados por el Estado argentino en el ejercicio de sus funciones de comprender, jurídica y formalmente, los hechos ejecutados por ese mismo Estado en el período de la dictadura. Esos materiales institucionales representan la espina dorsal de los posibles entendimientos e interpretaciones de este capítulo de la historia nacional, y también latinoamericana, con capacidad probatoria. El valor de prueba solo es garantizado por el mantenimiento de los vínculos archivísticos del acervo documental del ANM, como un todo. El aspecto problemático de que la institución trabaje sus documentos en departamentos, que ni siempre se conectan de manera integrada, no modifica el carácter archivístico de sus fotografías, puesto que están conectadas con los demás materiales de la Conadep, aunque no haya un instrumento general disponible al público.

Los materiales institucionales, fotográficos y no fotográficos, cumplen la función institucional de registro y prueba administrativa de las acciones del Estado en lo que atañe a la última dictadura, en tres momentos: el del conocimiento de los hechos, el de los hechos y el de las consecuencias del conocimiento jurídico de los hechos. A partir de esos materiales institucionales se construyó el concepto archivístico del ANM, basado en la noción del territorio de los derechos humanos. Es probable que el constructo no hubiera partido desde un plan teórico profundizado, pero, en términos prácticos, conformó el ANM como una institución archivística, de acuerdo a los principios de la disciplina. Alrededor de ese núcleo, con una acepción mucho menos estricta, como un repositorio de fuentes, se agregaron los demás materiales. Eso explica que, hasta la fecha, no haya una integración efectiva de los departamentos responsables por el tratamiento documental en función de sus géneros (documentos escritos, fotográficos, audiovisuales y archivo oral). ${ }^{26}$ Cada sector sigue su labor de manera más o menos independiente de los demás, lo que se puede notar, incluso,
26. Cf. $<$ https://bit. ly/3dGJ7Vh> y <https:// bit.ly/3fHAPhM $>$. 
27. Cf. $<$ https://bit. ly/2LvTrDn>.

28. Cf. $<$ https://bit. $1 \mathrm{y} / 2 \mathrm{zD} 41 \mathrm{Wt}>$.

29. Con relación a los conjuntos fotográficos cf. $<$ https://bit.ly/2LmS6ir>.

30. Cf. Carrafa (2011). Se podrían mencionar otros ejemplos, pero su profundización está fuera de los objetivos de este texto. por la falta de uniformidad de los instrumentos puestos a la consulta para los interesados y por la ausencia de una guía general del acervo de la institución.

Los materiales institucionales, sostenidos por el fondo Conadep, representan el elemento de unión, en la noción de territorio a los demás materiales del archivo. Alrededor de esa triada (Conadep-territorio de los derechos humanos-organicidad archivística) todo el acervo cobra sentido y se interconecta. En términos de los materiales fotográficos, las colecciones particulares sirven de apoyo y referencia; las colecciones de autores dejan de ser invisibles; la producción de Argra deja de ser solamente un banco de imágenes y se conecta al territorio; las copias de otras instituciones también salen de su invisibilidad. Al mismo tiempo que la tríada agrega otros materiales, ellos mismos contribuyen, por su vez, para el fortalecimiento del territorio y, por lo tanto, del carácter archivístico del ANM. De manera análoga, lo mismo ocurre con los documentos no fotográficos: el fondo documental autárquico del mundial de fútbol del 1978 gana valor al conectarse con el territorio; el archivo oral pasa a tener una base de apoyo formada por el mismo fondo Conadep; los audiovisuales y los "documentos escritos" (sic) se interconectan por la Conadep e, igualmente, traen consigo otros conjuntos no orgánicos, sacándolos de la invisibilidad y, al mismo tiempo, fortaleciendo el aspecto institucional del acervo.

Los materiales fotográficos del ANM aun colaboran, como insumos para la construcción visual de narrativas y de memorias nacionales, locales y len el caso del ANM) hasta latinoamericanas. Si las fotografías juegan el rol de insumos para la construcción de memorias, se puede decir que las instituciones que las gestionan, custodian y propician el acceso, operan como herramientas, como ejemplifican algunos casos. El mencionado AGM, en Cataluña, no solo se convirtió en la base de la construcción de narrativas y memoria gerundenses, como también, por medio del Centre de Recerca i Difusió de la Imatge ${ }^{27}$ (CRDI), se tornó en un modelo a ser seguido, desde la óptica archivística, en lo que atañe al tratamiento técnico y gestión de materiales filmicos y fotográficos. El Centro de Fotografía de Montevideo $(\mathrm{CdF})^{28}$ busca el reconocimiento sudamericano como institución clave para el tratamiento técnico de fotografías y como punto de referencia para la construcción de narrativas visuales sobre memoria e identidades uruguayas. En una perspectiva que va más allá de la archivología, aún se podría mencionar el trabajo de punta del Kunsthistorisches Institut in Florenz (KHI) ${ }^{29}$, en especial sobre la interrelación de los materiales fotográficos de archivo y la historia del arte. ${ }^{30}$

Seguir desmereciendo al ANM, con un discurso repetitivo de que no es un archivo y que es fruto de una políitica de memoria, es un gran equívoco, que apenas colabora con los intereses favorables a la ocultación de los documentos que prueban las graves violaciones contra los derechos humanos por el terrorismo del 
Estado. La estabilidad democrática en Latinoamérica, infelizmente, aún necesita estar más consolidada y el tema de las graves violaciones de los derechos humanos en la región sigue abierto (o con cicatrices muy recientes, según el país). Instituciones archivisticas - aquellas que tienen la capacidad de prueba - son fundamentales para revertir ese escenario, contribuyendo para que el terrorismo de Estado nunca más se repita. El sostenimiento del ANM, como archivo, colabora de sobre manera con la estabilidad democrática nacional y regional. 


\section{REFERENCIAS}

LIBROS, ARTÍCULOS Y TESIS

ARCHIVO NACIONAL DE LA MEMORIA. Guía de fondos: documentos fotográficos. Buenos Aires: ANM, 2018. Disponible en: <https://bit.ly/3fK48jK>. Acceso en: 27 abr. 2019.

ARGENTINA. Archivo Nacional de la Memoria: decreto 1259/2003. Boletín Oficial de la República Argentina, Buenos Aires, año 111, no 30.299, p. 01-02, 17 dic. 2003.

ARGENTINA. Créase en su ámbito la Subsecretaría de Derechos Humanos: decreto 3090/1984. Boletín Oficial de la República Argentina, Buenos Aires, año 92, nº 25,516, p. 02, 24 sep. 1984.

ARQUIDIOCESE DE SÃO PAULO. Brasil: nunca mais, 18 ${ }^{\mathrm{a}}$ ed. Petrópolis: Vozes, 1986.

BOADAS, J. Patrimonio fotográfico: propuesta para una gestión eficaz. In: OLIVERA ZALDUA, M.; SALVADOR BENÍTEZ, A. (Orgs.). Del artefacto mágico al píxel: Estudios de fotografía. Madrid: Fadoc/ UCM, 2014, p. 319328. Disponible en: <https://goo.gl/EIgSwT>. Acceso en: 27 abr. 2019.

CAMARGO, A. Os arquivos da polícia política como fonte. Registro, Indaiatuba, $\mathrm{n}^{\circ} 01, \mathrm{p}$. 0511, 2002. Disponible en: <https://bit.ly/2zD0BTD>. Acceso en: 27 abr. 2019.

CARAFFA, Costanza (ed.). Photo archives and the photographic memory of Art History. Berlin: München: Deutscher Kunstverlag, 2011.

COMISIÓN NACIONAL SOBRE LA DESAPARICIÓN DE PERSONAS. Nunca Más: Informe de la Comisión Nacional sobre la Desaparición de Personas, 11ª ed. Buenos Aires: EUDEBA, 1985.

DI PIETRO, L. Reflexões sobre fotografia, arquivo e direitos humanos. Photo $\mathcal{E}$ Documento, Brasília, n. 1, 2016. Disponible en: <https://bit.ly/3dCLto0>. Acceso en: 27 abr. 2019.

DUCHEIN, M. O respeito aos fundos em arquivística: princípios teóricos e problemas práticos. Arquivo \& administração, Rio de Janeiro, v. 10-14, n. 1, p. 14-33, 1986. Disponible en: $<$ https://bit.ly/3brxLCX>. Acceso en: 27 abr. 2019. 
GIRALDO LOPERA, M.; TORO TAMAYO, L.; ESTRADA SIERRA, A. Y MEJÍA ACEVEDO, V. Escuchar, guardar, abrazar: El archivo vivo de la Asociación Caminos de la Esperanza Madres de la Candelaria. Medellín: Proyecto Museográfico, 2015.

INSTITUTO DE POLÍTICAS PÚBLICAS DE DERECHOS HUMANOS MERCOSUR. Archivo Nacional de la Memoria. In: INSTITUTO DE POLÍTICAS PÚBLICAS DE DERECHOS HUMANOS MERCOSUR. Guía de archivos y fondos documentales. Disponible en: <https:// bit.ly/2zDkN8g>. Acceso en: 27 abr. 2019.

JENKINSON, H. A manual of archive administration, London: Percy Lund, Humphries, 1966.

LOPEZ, André Porto Ancona. Archivos y ciudadanía: el acceso a la información pública. Revista General de Información y Documentación, Madrid, n ${ }^{\circ}$ 21, p. 249264, $2011 \mathrm{~b}$. Disponible en: <https://bit.ly/2zvfkjD>. Acceso en 19 oct. 2019.

LOPEZ, André Porto Ancona. Contextualización archivística de documentos fotográficos. Alexandria, Lima, vol. 05, p. 0316, 2011a. Disponible en: <https://bit.ly/2WRA0KP>. Acceso en: 27 abr. 2019.

LOPEZ, André Porto Ancona. Documentos imagéticos de arquivo: uma tentativa de utilização de alguns conceitos de Panofsky. Sinopses, São Paulo, nº 31, p. 49-55, 1999.

LOPEZ, André Porto Ancona. Photographic document as image archival document. In: TEHNICNI IN VSEBINSKI PROBLEMI KLASICNEGA IN ELEKTRONSKEGA ARHIVIRANJA: Referatov dopolnilnega izobraževanja s podro?ij arhivistike, dokumentalistike in informatike v Radencih, 8. Maribor: PAM, p. 362-272, 2009. Disponible en: <http://eprints. rclis.org/12846/>. Acceso en: 27 abr. 2019.

PANOFSKY, E. Iconografia e iconologia: uma introdução ao estudo da arte da renascença. En PANOFSKY, E. O significado nas artes visuais. $3^{\text {a }}$ ed. São Paulo: Perspectiva, 1991, p. 47-87.

SILVA CATELA, L.; JELIN, E. Los archivos de la represión: documentos memoria y verdad. Madrid: Siglo XXI, 2002.

Artigo apresentado em 29/5/2019. Aprovado em 16/4/2020. (cc) BY

All the contents of this journal, except where otherwise noted, is licensed under a Creative Commons Attribution License 